\title{
The Art of Mystification
}

\section{Esotericism Differentiated in the Definition of Finnish Symbolism}

$\mathrm{I}_{\mathrm{o}}^{\mathrm{n}}$ magine this: a young girl rises from a red sea of clouds into the glow of a golden planet. Her palms are raised towards the high skies and her hair flames as though it were a fiercely burning fire or the sun itself. What do you think you would feel before this picture? And what should you?

These questions rose into my mind a couple of years ago when I stood before the painting I have just described-Ad Astra (1894, see illustration), one of the well-known works of the Finnish artist Akseli Gallen-Kallela (1865-1931). ${ }^{1}$ In the mid-1890s Gallen-Kallela created many of the paintings that were later connected with the Symbolist art movement, which originated especially in late nineteenth century France and was intertwined with Western esotericism in many ways. ${ }^{2}$ In Finland, Symbolism has been understood mainly through the definitions of one art historian, Salme Sarajas-Korte (b. 1925). She wrote an admiringly comprehensive study about the sources of the early Finnish Symbolist art in 1966 and ever since her views on Symbolism have been reproduced and referred to. ${ }^{3}$ So if you want to see Gallen-Kallela's Ad

1 In 1907 Gallen-Kallela made another version of the original Ad Astra, since he did not want to sell his own copy of the painting. He hid the stigmas from the first Ad Astra, but painted them quite visibly into the palms of the second heroine. (Rapetti 2000: 51-2.)

2 For Symbolism's connection to esotericism see e.g. Pincus-Witten 1976 and Tuchman 1986.

3 Sarajas-Korte's study Suomen varhaissymbolismi ja sen lähteet. Tutkielma Suomen maalaustaiteesta 1891-1895 (The Early Finnish Symbolism and its Sources. A study of Finnish Painting in 1891-1895) was her doctoral thesis. Her views about Finnish Symbolism have influenced for example the writings of Riikka Stewen (1996, 2001), Elina Bonelius (2003), Anna-Maria von Bonsdorff (1998) and Juha-Heikki Tihinen (2008). At the time of writing (15.6.-2.9.2007), there 
Astra as a Symbolist work of art, you should definitely see and feel it through the definitions made by Sarajas-Korte in the 1960s-at least if you want to agree with the canonized comprehension about this picture and about Finnish Symbolism.

In this article I will focus on Sarajas-Korte's definitions that proved to be so significant to Finnish art history. In spite of the fact that her research still represents the most extensive and profound work on Finnish Symbolism, my aim here is to question some of her definitions and categorizations. Most of her concepts are puzzling, since she tends to use them in several different ways. One example of her conceptualizations is the way she uses the word esotericism and its derivatives. First of all, she seems to associate esotericism with secrecy and things hidden-in other words she follows the definition created already by the ancient Greeks (see e.g. von Stuckrad 2005: 1; Hanegraaff 2005a: 336-7). Secondly, she fuses esotericism with Symbolism as she herself defines it; hence Symbolist art is grounded on the 'esoteric conceptions of symbols'. She also uses the word esotericism as though it would reflect the spirit of an age, as she writes for example about 'the esoteric youth' of the time. In addition to these three meanings, Sarajas-Korte seems to understand esotericism also by means of tradition. Her view of the esoteric tradition, however, is quite inclusive, since it seems to contain everything from the secret societies of Joséphin Péladan to the stories of the Bible and the Ramayana. ${ }^{4}$

As this example shows, the concepts Sarajas-Korte uses in her study are not by a long shot easy to define and thus the remarks I make in this article will unavoidably be harsh simplifications. My intention here is, nevertheless, to dig around her conceptualizations and drag out some

is an exhibition called 'Music and Silence. Finnish Symbolism' at the Ateneum art museum in Helsinki, curated by Laura Gutman-Hanhivaara, whose comprehension of Finnish Symbolism also echoes the definitions made by SarajasKorte (see Gutman-Hanhivaara 2007). Recently some Finnish art historians, however, have been given up Sarajas-Korte's approach to Symbolism (see e.g. Kalha 2005, von Bonsdorff 2007, Tihinen 2006).

4 Sarajas-Korte refers to different meanings of esotericism as follows: esoteric as hidden or secret (see e.g. 1966: 34, 115), esoteric in connection to Symbolism (see e.g. 1966: 40), esotericism as Zeitgeist (see e.g. 1966: 55-6) and esoteric tradition (see 1966: 55, 85). The prevalent scholarly view on the esoteric tradition has later been established mainly on the basis of Antoine Faivre's (1994: 10-15) definition of esotericism as a form of thought. 
questionable differentiations she constructs while defining Symbolist art. From the sketchy list of the meanings Sarajas-Korte ascribes to esotericism, I will now move on to a more detailed analysis of her definitions pertaining to Symbolist art and its spirituality.

\section{The Spiritual Mysticism: Defining Symbolist Art}

In his famous article of 1891 about Symbolist art theory, the French critic G.-Albert Aurier (1865-92) used Plato's allegory of the cave as his starting point. Whereas former artists had been content to paint only the forms of the shadow world, Symbolists were now reaching for the absolute reality (See Aurier 1995: 195-203). Over six decades later Salme Sarajas-Korte (1966: 29-31, 40-3) cherished Aurier's comprehension and ended up emphasizing the Platonic grounds of Symbolism above everything else. In her opinion, the revolution of Symbolist thinking was founded first and foremost on Plato's philosophy: Symbolism 'wished to open a view for the artist . . beyond the quasi-world of senses into the spiritual reality, into the Platonic world of Ideas' ${ }^{5}$ (Sarajas-Korte 1966: 29). In other words, the Symbolist artist was ultimately meant to experience the divine reality of the Absolute Ideas-and specifically the Idea of Beauty. Due to Sarajas-Korte's emphases, her definition of Symbolism appears to be constructed primarily on Plato's theories. Furthermore, the centrality of Platonism is expressed in Sarajas-Korte's tendency to reduce other religious-philosophical ideologies back to 'their Platonic roots', too. ${ }^{6}$

The influence of Plato is emphasized for instance in relation to Emanuel Swedenborg (1688-1772), whose theological doctrine of correspondences Sarajas-Korte specifies as the second major influential force behind Symbolism. According to Swedenborg's theory, the separate natural and spiritual worlds communicate with each other through correspondences, and thus every worldly thing responds to some entity in the celestial world. This interconnectedness also concerns the worldly human

5 All translations of Sarajas-Korte by the author.

6 Sarajas-Korte (1966: 32-3) traces, for example, Swedenborg's worldview back to Platonism and Christianity through Neo-Platonism. She also believes that the same Platonic ground is fundamental to Baudelaire's aesthetics, although she admits that the writer himself mentions Swedenborg's name more often than Plato's. 


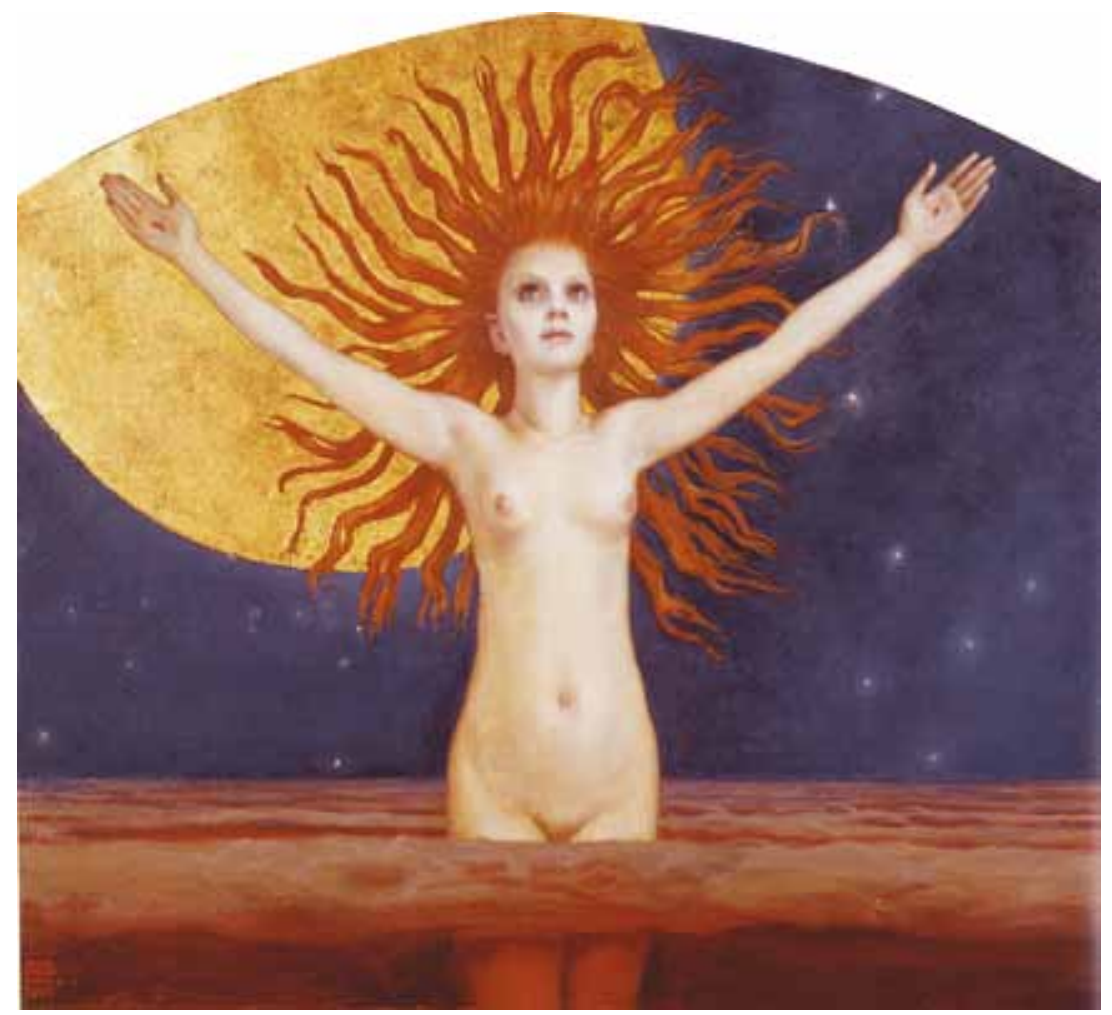

Ad Astra (1894) by Akseli Gallen-Kallela.

being, who as a microcosm is linked to both realms, natural and spiritual-celestial, although the latter is reachable to him only through correspondences. From the viewpoint of Symbolist theory this means that the lines and shapes of the artwork are connected to the artist's spiritual inner structure, which, in its turn, is related to celestial reality. Thus artworks can relate to the spiritual realm through the artist (Sarajas-Korte 1966: 31-2, 104-5. See also Williams-Hogan 1998: 218-20).

Besides Swedenborg's correspondences, the pathway to Platonic transcendence can be opened up by the means of love and ecstasy. At this point Sarajas-Korte adds the third religious-philosophical element into her definition of Symbolist theory - the Neo-Platonism of Plotinus. She believes that the ideas of Plotinus had something to do with the fact that Symbolist artists came to appreciate intuitive concentration and the state of ecstasy as means to unite with the higher spiritual reality. Yet again, it is also Plato's influence Sarajas-Korte (1966: 30) wants to 
emphasize here, since from her point of view Plato's doctrine of Eros 'leads into the centre of Symbolist aesthetics'. Love in its purest form is directed towards the Idea of the Beauty and thus it guides the artist when he or she seeks union with the transcendental. Thus, Eros is an intermediary force between the perceptible realm and the Absolute. What is important to notice here is the fact that in Sarajas-Korte's Symbolism, the notions of love and ecstasy play major roles: according to her, such famous Symbolists as Charles Baudelaire (1821-67) and Paul Gauguin (1848-1903) were reaching for the transcendence in the altered state of consciousness, the soul's ecstasy (Sarajas-Korte 1966: 30-7).

It is on these three grounds-(1) Plato's Idea-realm and theories of Eros, (2) Swedenborg's doctrine of correspondences and (3) the ecstasy of Plotinus-that Sarajas-Korte constructs her definition of Symbolism. ${ }^{7}$ It is an art movement seeking union with the divine reality, which lies beyond the mundane perceptions of the senses. The function of the artist, who reaches for the transcendental either by contemplating her own inwardness or in a state of visionary ecstasy, is to express the Absolute through her artwork (Sarajas-Korte 1966: 8-10 and 1989: 255-6).

What is noteworthy in this description is its close resemblance to the notion of mysticism, which is commonly conceptualized around the idea of the mystic's unifying experience of the divine presence (see e.g. McGinn 2000: xvi-xvii; Rousse-Lacordaire 2005: 818-19). Sarajas-Korte (1966: 32) herself underlines this connection, as she claims that 'it is usually hard to decide where religious mysticism ends and the Symbolist art theory begins'. Even if the concepts that Sarajas-Korte uses are not always unambiguous, I would presume the relation between Symbolism and mysticism is knowingly constructed. But why it is so important that the art movement in question should be understood in these terms? And why is Sarajas-Korte so eagerly trying to trace everything-at least in some part-back to Plato's philosophy? Could it be that she is avoiding some disturbing categories into which she does not wish Symbolist art and the mysticism it represents to fall?

7 In her later writings Sarajas-Korte (1989: 256) admits that Theosophy also played an important role in the birth of Symbolism, but in her doctoral thesis this fact is still left somewhat unclear. I will get to the specifics of this point later in this article. 


\section{The Mysticism of Sciences: Demarcating the Possibility of Superstition}

According to Sarajas-Korte (1966: 15-17, 51-4), the mysticism that Symbolism laid its grounds on had its forerunner in the somewhat doubtful atmosphere of the 1880s, which was dominated by 'sciences' aiming to study the spiritual world. ${ }^{8}$ At the time, such phenomena as Spiritualism, Mesmerism 9 , Occultism and Theosophy ${ }^{10}$ were blurring the dividing line between scientific knowledge and religious faith. Artists were fascinated by Doctor Jean-Martin Charcot's hypnotic shows and participated in spiritualist séances held all over Paris. From Sarajas-Korte's point of view, these phenomena were none but symptoms of the more serious and sophisticated spirituality, which later rose from the ashes of the pseudo-rational atmosphere of the 1880s: 'it was through some sort of mysticism of the sciences that the spiritual mysticism of the 1890s was approached' (Sarajas-Korte 1966: 16, my italics).

The citation indicates that Sarajas-Korte assumed there were different forms of mysticism flourishing before the turn of the century, and that one of these mysticisms was somehow more spiritual-and also purer-than the others. For her this spiritual mysticism ${ }^{11}$ is intercon-

'"Sciences" aiming to study the spiritual world' is the expression SarajasKorte (1966: 17) uses. In another context she (1966: 53) also mentions 'occult science', which she seems to understand in a somewhat narrower meaning. In any case, Sarajas-Korte's usage of these terms connects her with polemics that have flourished around the concept of occult sciences since the Enlightenment: modern Theosophists and occultists have used the term as they have referred to their own superior worldview opposing materialism, positivism and dogmatic Christianity, whereas critics related it to irrationality and superstition. (Hanegraaff 2005c: 886-7.) The manner in which Sarajas-Korte uses these terms implies that she is—at least faintly-promoting the latter standpoint.

9 Sarajas-Korte (1966: 17) does not mention Mesmerism explicitly, but she writes about Doctor Charcot's hypnotism, which is part of the larger movement of Animal Magnetism/Mesmerism. It is also noteworthy that in France Mesmerism was closely intertwined with Spiritualism (see Meheust 2005: 79; Deveney 2005: 1080). For the sake of clarity I will in this article only use the concept of Mesmerism, when referring to the phenomenon.

10 In this article, Theosophy refers to the currents directly or indirectly connected with the Theosophical Society from the nineteenth century onwards. For the two different definitions of Theosophy, see Faivre 2000: 3-5.

11 As far as I have noticed Sarajas-Korte (1966: 16) uses this term in her study only once. The underlying difference between the various religious-philosophical 
nected with the 'genuine' esoteric-mystical conception of symbols, which gets its inspiration from Plato's Ideas and Swedenborg's correspondences-in other words it represents Symbolism as Sarajas-Korte herself defined it. One of the artists whom Sarajas-Korte (1966: 36-7 and 1989: 256) considers to be working under the influence of this specific mysticism is the painter Paul Gauguin (1848-1903). He is the one artist Sarajas-Korte seems to consider as qualified for her category of true Symbolists. For Gauguin 'the colours and lines of the painting, its inner tone and structure were able to provide an experience, which had its connection only with the human being's most intimate, inner self-with the unexplainable, undivided mystical experience' (Sarajas-Korte 1966: 37). But if Gauguin's spiritual mysticism was the only one qualified as a suitable basis for the Symbolist theory, what made the other forms of mysticism so unsuitable? Why, for example, was a Spiritualism representing the mysticism of the sciences an unacceptable source of inspiration for the Symbolist artist?

Wouter J. Hanegraaff has suggested that it could be useful to distinguish between three general strategies of knowledge when trying to understand Western esotericism. The first strategy relies on human reason and is commonly used in scientific research and rational philosophy. The second strategy is essential for the established religions since it depends on some commonly accepted divine revelation, which is believed to transcend mere human wisdom. There is little doubt that these two strategies of knowledge, having their roots in Greek philosophy and in biblical faith, have been dominant forces in Western culture. From the earliest centuries onwards, however, there has also been a third strategy, referred to as gnosis. It emphasizes the personal experience or inner revelation, which leads into an encounter with one's true self as well as with the divine grounds of being. This third strategy of knowledge has been in constant conflict with the other two, since it seems to overstep some essential boundaries. From the perspective of philosophy and science, gnosis is reaching for the truth 'beyond reason': the rational worldview is threatened for example by Hermeticism, since it operates too closely with modern science but does not necessarily adhere to the

phenomena, however, is implicated generally throughout the whole study. I chose to use the two concepts of mysticism of sciences and spiritual mysticism in order to have simple means to refer to Sarajas-Korte's divisions. Obviously I do not support this differentiation that she has constructed between the mysticisms. 
limits of mere rationality. On the other hand, the established religions seem to share a view that gnosis is bypassing important authorities by emphasizing the personal revelation and thus pulling itself away from 'true religion'. This position has called forth the discourse of heresy for example in the case of Gnosticism of late antiquity (Hanegraaff 2004: 409, 510-11; van den Broek \& Hanegraaff 1998: vii-x).

These three strategies of knowledge may shed some light on the divisions Sarajas-Korte makes between different forms of mysticism. By disentangling spiritual mysticism from the mysticism of sciences, SarajasKorte draws a strong boundary between Symbolist art and such esoteric phenomena as Spiritualism and Mesmerism. For her these obscure sciences seem to represent little more than mere superstition in which 'true' Symbolist artists like Gauguin could never seriously believe. The diminishing of the mysticism of sciences is also expressed in the way Sarajas-Korte uses the terminology of illness and bacteria in relation to it: for example, interest in Hypnotism was 'spreading like an epidemic' in the streets of the Parisian art world (See e.g. Sarajas-Korte 1966: 17). From my point of view, it certainly seems that Sarajas-Korte is trying here to protect both Symbolism and the spiritual mysticism it is based on from getting 'beyond reason'. She assimilates the standpoint of rationalists and points her finger at the superstitious and superficial nature of those 'sciences' aiming to study the spiritual realm. The mysticism of the Symbolists by contrast has little or nothing to do with these pseudo-sciences. What is noteworthy here is that by separating the different forms of mysticism from each other, Sarajas-Korte manages to keep the spirituality of Symbolist art apart from the filth of superstition and irrationality. Yet her differentiation between mysticisms is actually quite understandable, since up until recently many of the esoteric phenomena have been understood as somewhat problematic for scientific research (Hanegraaff 2005b). So in a way her views were nothing out of the ordinary in the academic milieu of the 1960s.

Sarajas-Korte's tendency to protect Symbolism from the dubious influence of irrational gnosis also makes me wonder whether it could be possible that she emphasizes the relation between Symbolism and Platonic philosophy for the same reasons. As the roots of Hanegraaff's rational strategy of knowledge lie in the midst of Greek antiquity, philosophy could certainly add some seriousness into the art theory SarajasKorte otherwise so clearly connects with mysticism. In any case, SarajasKorte seems to be eager to direct Symbolism further away from the mysticism of the sciences and nearer to the philosophical contemplation, as she promotes the idea that by the 1890 s 'mysticism had found its way 
from the level of Spiritualist séances ... into the serious conversations of the modern philosophy' (Sarajas-Korte 1966: 51).

The definition of Theosophy constitutes an interesting case study if you want to pay attention to the differentiation Sarajas-Korte establishes, since it seems to be situated in some sort of an ambivalent intersection between spiritual mysticism and the mysticism of the sciences. In other words, Theosophy does not clearly represent either one of these mysticisms, but has something in common with both of them. First of all, Sarajas-Korte (1966: 15-17) seems to think that Theosophy gained its popularity in the imminence of other forms of mysticism of sciences: it shares the same fusion of faith and knowledge as for example Spiritualism and Occultism, and hence it is at risk to be categorized as superstition. The threat is expressed by Sarajas-Korte when she suggests that Theosophical doctrines and writings were often speculative and even uncritical. ${ }^{12}$ These remarks indicate that she estimates the value of this religious-philosophical movement using the criteria of rational science-no wonder Theosophy appears to be questionable! On the other hand, Theosophy also seems to have some characteristics that would favour its relocation into the respectable category of spiritual mysticism forming the grounds for the Symbolist art. Here the notion of philosophy comes up again as Sarajas-Korte (see e.g. 1966: 51, 60, 111) connects Theosophy with Eastern wisdom and mysticism. ${ }^{13}$ On several occasions she only writes about Eastern philosophy, and I would presume that by this she means to refer to some Theosophical sources-only in a more suitable form. She does not for example mention Theosophy in relation to Paul Gauguin - the one artist she believes discovered the possibilities of spiritual mysticism in art-although his Finnish art students were reading the writings of A. P. Sinnet ${ }^{14}$ with great enthusiasm.

12 Sarajas-Korte (1966: 53) connects Theosophy specifically with Edouard Schuré, who wrote the influential Les Grands initiés in 1889. Although Sarajas-Korte's summary about Schuré's doctrines brings forth the micro- and macrocosmic relations, she does not point out the similarities between the Platonic-Swedenborgian mysticism and Schuré's thinking-instead she remarks that Schuré wrote 'fairly uncritically' about the shared history of different religions. She (1966: 51) also states that Theosophy was often quite speculative in its nature.

13 Although Theosophy derived its doctrines from Hinduism and Buddhism among others, it is obvious that it used these sources selectively for its own purposes. In Sarajas-Korte's writings this fact does not become clear.

14 Paul Gauguin's Finnish students Pekka Halonen (1865-1933) and Väinö Blomstedt (1871-1947) read A. P. Sinnet's book entitled Esoteric Buddhism during the 
Only Gauguin's interest in Eastern mysticism is noted (Sarajas-Korte 1966: 36-9, 111-15). It is as though Sarajas-Korte was struggling between the two categories: as Eastern philosophy and mysticism, Theosophy would be good enough to represent spiritual mysticism, but it still had too many similarities with pseudo-sciences like Spiritualism. To avoid the stigma of superstition in relation to Symbolism, she seems to be more willing to write about the Eastern influences than about Theosophy per se.

\section{Imagining Symbolism ${ }^{15}$}

In the late fifteenth century, the well-known renaissance humanist Marsilio Ficino (1433-99) tried to redeem his magical texts and rituals from the demonizing interpretations of Christians by hiding behind NeoPlatonic authorities and the notion of magia naturalis, which made the magical operations seem more natural or even scientific (von Stuckrad 2005: 63-4). In other words Ficino made use of the philosophy and language of science as he tried to protect his own ideological context. Considering Salme Sarajas-Korte's conceptual divisions from this point of view, I have to wonder if she finally discovered the same thing that Marsilio Ficino did several centuries earlier: that if you want to get rid of the stigma of superstition, you can always try to hide behind philosophy and scientific rhetoric. In any case, her definitions seem to protect Symbolist art from being confused with the phenomena that might seem absurd and superstitious in the eyes of 'rational readers'.

winter of 1893-4 (Sarajas-Korte 1966: 111). The book sums up the teachings Sinnet claims to have gathered while in contact with the same Mahatmas or Masters of Wisdom that were the basis for Helena P. Blavatsky's theosophical doctrine (Santucci 2005: 1116).

15 The heading refers to Jonathan Z. Smith's insightful study Imagining Religion: From Babylon to Jonestown (1988). In this book Smith (1988: xi) states that religion is solely the theoretical creation of scholars, who use it for their own analytical purposes. My overall comprehension of Symbolism is similar: there is no pre-existent art movement called Symbolism, which unfolds itself before the willing art historian. Thus there cannot be any purer or authentic forms of this art movement either, and this is exactly what Sarajas-Korte seems to be suggesting. 
In addition, Sarajas-Korte's definitions also disentangle Symbolism from the burden of social-political issues. By combining Symbolism with mysticism, she is demarcating Symbolist art into the private spiritual domain, which is conveniently separated from the realms of the secular, political and public. ${ }^{16}$ Thus her definition seems to partake in the mystification ${ }^{17}$ of Symbolism, which is still quite a common tendency in many art historical studies (Hirsch 2004: xiii). One explanation for SarajasKorte's eagerness to emphasize the Platonic grounds of Symbolism can in fact be seen in relation to this mystification. Since Christian mysticism is often claimed to be inspired by Plato's philosophy and especially by his theories of Love/Eros as a pathway to transcendence (Louth 1981: 191-204; McGinn 2000: 24-35), Symbolism and Christian mysticism would suddenly seem to hold essential similarities. This association between mysticism and the art movement in question, in its turn makes Symbolism appear as a 'purely spiritual' phenomenon, which has little or nothing to do with the secular realm of politics.

Although I still consider Salme Sarajas-Korte's study to be the most comprehensive research on the connections between Western esotericism and Finnish Symbolism, her writings nevertheless make some questionable divisions concerning different esoteric currents, mysticisms and politics. In her writings she constructed an art movement destined to live in its pristine spiritual realm. Symbolism was covered with the aura of mysticism and protected from the harms of accusations of superstition by emphasizing philosophical roots of the art movement. This overall definition also guides Sarajas-Korte as she interprets Akseli Gallen-Kallela's Ad Astra. The painting is full of mysticism, but it also reflects the religious crisis the artist went through as he was exposed to Theosophical influences: Gallen-Kallela's comprehension of art was shaken and the whole period of crisis was dominated by an unnatural

16 I am planning to get into the specifics of this separation in my doctoral thesis. At this point I can only note that this division has led into the situation where it is necessary to categorize different artist and artworks either as Symbolist-spiritual or as national-political. Russell T. McCutcheon (2003) and Bruce Lincoln (1999) among others have pointed out the importance of such constructed divisions.

17 By mystification I refer to similar action that McCutcheon (2000: 205-7) defines as mythmaking: in order to create a safe haven for something, the complex network of disguised assumptions is utilized and attention is drawn away from questions that are not wanted. 
foreign ambition' (Sarajas-Korte 1966: 292-5). I can but wonder, how Gallen-Kallela's painting and Finnish Symbolism in general would look like, if they were released from their own spiritual realm into the reality full of uncomfortable social-political negotiations and struggles. How would they appear in this mundane context? And what would happen to Ad Astra if it were associated with such phenomena as Occultism and Theosophy without the fear of being condemned as superstitious or heretic? ${ }^{18}$ Imagine if Symbolist art was redefined without the aura of spirituality and the hierarchic differentiation between mysticisms. Imagine Ad Astra all over again.

\section{References}

\section{Aurier, G.-Albert}

1995 Symbolism in Painting: Paul Gauguin. In: Henri Dorra (ed.), Symbolist Art Theories: A Critical Anthology; pp. 192-203. Berkeley \& Los Angeles: University of California.

\section{Bonelius, Elina}

2003 Taidetta mystisen ykseyden tiellä. In: Anneli Ilmonen et al. (eds), Mystiikan portit; pp. 19-31. Tampere: Tampereen taidemuseo.

\section{Bonsdorff, Anna-Maria von}

1998 Ihminen vaeltaa maailmassa kuin symbolien metsässä - Pekka Halonen luonnonmystikkona. In: Ville Lukkarinen (ed.), Taide ja okkultismi: kirjoituksia taidehistorian rajamailta; pp. 41-51. Helsinki: Taidehistorian seura.

2007 Reflecting the Past and the Future - Finnish Art at the Turn of the 20th Century. Paper presented at the Towards a Science of Art History seminar, December 7-8, in Helsinki, Finland.

Broek, Roelof van den \& Wouter J. Hanegraaff

1998 Preface. In: Roelof van den Broek \& Wouter J. Hanegraaff (eds), Gnosis and Hermeticism from Antiquity to Modern Times; pp. vii-x. New York: University of New York.

\section{Deveney, John Patrick}

2005 Spiritualism. In: Wouter J. Hanegraaff et al. (eds), Dictionary of Gnosis $\mathcal{E}$ Western Esotericism; pp. 1074-82. Leiden: Brill.

18 The Frenchman Rodolphe Rapetti (2000) has already in a less evaluative manner suggested the significance of Theosophy and Esotericism in general in Ad Astra. Furthermore, the aspects of mundane cultural negotiations are vividly present in Harri Kalha's (2005) study about the discursive presentations of the Finnish Symbolist painter Magnus Enckell (1870-1925). 


\section{Faivre, Antoine}

1994 Access to Western Esotericism. New York: SUNY.

2000 Theosophy, Imagination, Tradition: Studies in Western Esotericism. New York: SUNY.

\section{Gutman-Hanhivaara, Laura}

2007 Musiikki ja hiljaisuus. Taide 3: 25-33.

Hanegraaff, Wouter J.

2004 The Study of Western Esotericism. New Approaches to Christian and Secular Culture. In: Peter Antes, Armin W. Geertz \& Randi R. Warne (eds), New Approaches to the Study of Religion. Volume 1: Regional, Critical, and Historical Approaches; pp. 489-519. Berlin: Walter de Gruyter.

2005a Esotericism. In: Woulter J. Hanegraaff et al. (eds), Dictionary of Gnosis $\mathcal{E}$ Western Esotericism; pp. 336-40. Leiden: Brill.

2005b Forbidden Knowledge: Anti-Esoteric Polemics and Academic Research. Aries 5 (2): 225-54.

2005c Occult/Occultism. In: Woulter J. Hanegraaff et al. (eds), Dictionary of Gnosis \& Western Esotericism; pp. 884-9. Leiden: Brill.

\section{Hirsh, Sharon L.}

2004 Symbolism and Modern Urban Society. Cambridge: Cambridge University.

Kalha, Harri

2005 Tapaus Magnus Enckell. Helsinki: Suomalaisen Kirjallisuuden Seura.

\section{Lincoln, Bruce}

1999 Theorizing Myth: Narrative, Ideology, and Scholarship. Chicago \& London: University of Chicago.

\section{Louth, Andrew}

1981 The Origins of the Christian Mystical Tradition from Plato to Denys. New York: Oxford University.

McCutcheon, Russell T.

2000 Myth. In: Willi Braun \& Russell T. McCutcheon (eds), Guide to the Study of Religion; pp. 190-208. London and New York: Cassell.

2003 The Discipline of Religion: Structure, Meaning, Rhetoric. London \& New York: Routledge.

\section{McGinn, Bernard}

2000 The Foundations of Mysticism. Origins to the Fifth Century. New York: Crossroad. (The Presence of God. A History of Western Christian Mysticism, Vol. 1)

\section{Meheust, Bertrand}

2005 Animal Magnetism/Mesmerism. In: Wouter J. Hanegraaff et al. (eds), Dictionary of Gnosis \& Western Esotericism; pp. 75-82. Leiden: Brill.

\section{Pincus-Witten, Robert}

1976 Occult Symbolism in France. New York \& London: Garland Publishing.

Rapetti, Rodolphe

2000 Ad Astra: Gallen-Kallela ja kansainvälinen symbolismi. In: Riitta Ojanperä et al. (eds), Tuntematon horisontti. Suomen taidetta 1870-1920; pp. 4859. Helsinki: Ateneum / Valtion taidemuseo. 


\section{Rousse-Lacordaire, Jérôme}

2005 Mysticism. In: Wouter J. Hanegraaff et al. (eds), Dictionary of Gnosis $\mathcal{E}$ Western Esotericism; pp. 818-20. Leiden: Brill.

\section{Santucci, James A.}

2005 Theosophical Society. In: Wouter J. Hanegraaff et al. (eds), Dictionary of Gnosis E Western Esotericism; pp. 1114-23. Leiden: Brill.

\section{Sarajas-Korte, Salme}

1966 Suomen varhaissymbolismi ja sen lähteet. Tutkielma Suomen maalaustaiteesta 1891-1895. Helsinki: Otava.

1989 Maalaustaide 1890-luvulla - mystiikkaa vai kansallisromantiikkaa. In: Salme Sarajas-Korte et al. (eds), Ars: Suomen taide 4; pp. 254-93. Espoo: Weilin+Göös.

\section{Smith, Jonathan Z.}

1988 Imagining Religion: From Babylon to Jonestown. Chicago: University of Chicago.

\section{Stewen, Riikka}

1996 Suljetut silmät. In: Pirjo Lyytikäinen, Jyrki Kalliokoski \& Mervi Kantokorpi (eds), Katsomuksen ihanuus. Kirjoituksia vuosisadanvaihteen taiteista; pp. 17-26. Helsinki: Suomalaisen Kirjallisuuden Seura.

2001 Symbolistia suuntauksia 1890-luvulla. In: Helena Sederholm et al. (eds), Pinx. Maalaustaide Suomessa: suuria kertomuksia; pp. 232-45. Espoo: Weilin+Göös.

\section{Stuckrad, Kocku von}

2005 Western Esotericism. A Brief History of Secret Knowledge. London \& Oakville: Equinox.

\section{Tihinen, Juha-Heikki}

2007 Halun häilyvät rajat. Magnus Enckellin teosten maskuliinisuuksien ja feminiinisyyksien representaatioista ja itsen luomisesta. Helsinki: Taidehistorian seura. (Taidehistoriallisia tutkimuksia - Konsthistoriska studier, 37)

\section{Tuchman, Maurice}

1986 Hidden Meanings in Abstract Art. In: Maurice Tuchman et al., The Spiritual in Art: Abstract Painting 1890-1985; pp. 17-61. New York: Los Angeles County Museum of Art \& Abbeville Press.

\section{Williams-Hogan, Jane}

1998 The Place of Emanuel Swedenborg in Modern Western Esotericism. In: Antoine Faivre \& Wouter J. Hanegraaff (eds), Western Esotericism and the Science of Religion; pp. 201-52. Leuven: Peeters. 